pans, where an estimated 500,000 $\mathrm{kg}$ are harvested annually, sustaining cultural traditions such as fonya basket fishing.

Ndumo is also an Important Bird Area, with over 400 species. Hippopotamuses breed there, and it is one of only three sanctuaries for wild Nile crocodiles Crocodylus niloticus in South Africa. The main crocodile nesting area is now disrupted by farming and gill-netting. This area formerly provided winter grazing for antelope species, the rhinoceros (now all gone) and hippopotamus, and also protects rare plants, including sand forest endemics on its fringes.

Reasons why the Mbangweni/Bhekabantu communities cut Reserve fences in 2008, and perhaps for the farming since then, revolve around a disputed land claim dating from 200o. There are allegedly two agreements: one confers co-management with benefits but no occupation, the other (which cannot be located) allegedly grants right to occupy Reserve land. Apparently, compensation remains unpaid. Exacerbated by poor relations between conservation authorities and communities-causes of which include historical evictions and violent encounters in poaching incidentsagreement on co-management has proved elusive.

Dispute resolution efforts have been made, and plans developed to support local livelihoods outside the Reserve. However, failure of one funded plan, continuing lack of resources, local disagreements, and political interference with re-establishing the fence mean conflict persists. There is a danger this longrunning occupation will become accepted as the status quo.

In the face of political instability, apparent immunity for expanding illegal land conversion, local poverty and an untenable conservation management situation, the Reserve's future is threatened, with potentially negative consequences for other protected areas in KwaZulu-Natal Province. The conservation authority Ezemvelo KZN Wildlife has indicated these complex issues of encroachment require multiagency intervention, and as such Ezemvelo has requested that Ndumo Game Reserve be identified as a priority for a national support and intervention programme.

SIMON PoOLEY (@ orcid.org/ 0000-0002-0260-6159) Department of Geography, Birkbeck University of London, London UK, and School of Life Sciences, University of KwaZulu-Natal, Pietermaritzburg, South Africa E-mails.pooley@bbk.ac.uk

This is an Open Access article, distributed under the terms of the Creative Commons Attribution licence CC BY NC SA 4.0.

\section{Endangered Australian marsupial species survive recent drought and megafires}

The 2019-2020 megafires burned vast swathes of southeastern Australia-almost 12.6 million ha (Wintle et al., 2020, TREE, 35, 753-757). For some areas on Australia's east coast that escaped burning, prolonged drought preceding the fires had placed plant and animal populations under duress for several years.

Across this period, we have monitored two nationally Endangered carnivorous marsupial species that occur patchily in restricted high-elevation wet forests of eastern Australia (Environment Protection and Biodiversity Conservation Act 1999; undergoing IUCN Red List assessment). The black-tailed dusky antechinus Antechinus arktos has been severely affected by drought. The silver-headed antechinus Antechinus argentus has been both affected by drought and directly impacted by the megafires. We found both antechinus species persisting in mid 2020, after the megafires, but populations of each have suffered in different ways.

Although only limited known habitat of $A$. arktos was burned, our annual monitoring since 2014 shows this species has suffered major declines since 2019 at its type locality and former stronghold of Springbrook National Park, Queensland. Not only have we failed to catch A. arktos there in the past 3 years (in 2015, we had 30 captures), but our captures of co-occurring once common species, such as the brown antechinus Antechinus stuartii and native rodents, have declined by up to 10-fold. However, as well as live capture and camera traps, we have employed a canine detection team to help study this population. Although general findings indicate detections have diminished since 2017, the dog team found A. arktos at Springbrook in 2019 and 2020; unfortunately, most of the 2021 surveys were cancelled because of the COVID-19 pandemic.

Antechinus argentus has suffered major impacts to its habitat from the extensive bushfires of 2018 and the 2019-2020 megafires. In Queensland's Bulburin National Park, which may support the largest population, over 3,00o ha of rainforest and wet eucalypt forest burned in 2019 (Melzer et al. (2020) Post-Fire Assessment Report - Natural Values: 2019/2020 Bushfire, Bulburin National Park, South East Queensland Region. Department of Environment and Science, Queensland Government, Brisbane, Australia), c. one-third of suitable $A$. argentus habitat in Bulburin.

Dog and trapping surveys in 2020 and 2021 found A. argentus at several regenerating burnt sites at Bulburin. We had hoped for recovery of the A. arktos population after the return of rain this past summer, but three rounds of trapping in JuneAugust 2021 at Springbrook failed to capture any individuals.

This research is supported by the Australian Government's Bushfire Recovery for Wildlife and their Habitats programme, the National Environmental Science Programme, the New South Wales Government's Saving our Species programme, and WWF-Australia.

ANDREW M. BAKER (○ orcid.org/0000-0001-8825-1522) Queensland University of Technology, Brisbane, Australia, \& Biodiversity and Geosciences Program, Queensland Museum, Brisbane, Australia.E-mailam.baker@qut.edu.au 
STEPHANE BATISTA (๑ orcid.org/0000-0002-8245-9186) Queensland University of Technology, Brisbane, Australia

MELINDA J. LAIDLAW (৫ orcid.org/0000-0001-5686-0753) Department of Environment and Science, Brisbane, Australia

LYNN M. BAKER (๑ orcid.org/0000-0002-2803-761X) Canines for Wildlife, Bellingen, Australia

IAN C. GYNTHER (๑ orcid.org/0000-0002-0645-4746) and

HARRY B. HINES (๑ orcid.org/0000-0001-5547-5693)

Department of Environment and Science, Brisbane, Australia, and Biodiversity and Geosciences Program, Queensland Museum, Brisbane, Australia

DIANA O. FISHER (○ orcid.org/0000-0002-4017-3710)

University of Queensland, Brisbane, Australia

This is an Open Access article, distributed under the terms of the Creative Commons Attribution licence CC BY NC ND 4.0.

\section{Integrating Javan leopard conservation into a UNESCO Biosphere Reserve in East Java, Indonesia}

The Endangered Javan leopard Panthera pardus melas is endemic to Java, one of the most populated islands, where it occurs in 22 isolated forest patches that comprise $<9 \%$ (c. 1.2 million ha) of the island's total land area. Fewer than 400 adults remain in the wild; most of the extant subpopulations will not survive unless conservation actions for this subspecies are improved. One of the best opportunities to connect Javan leopard subpopulations are the UNESCO Biosphere Reserves, including the Belambangan Biosphere Reserve in East Java. The Reserve incorporates three National Parks and one Nature Reserve (Meru Betiri, Alas Purwo, Baluran and Kawah Ijen) as core areas that together secure c. 78,000 ha of forest. The adjacent buffer zones provide an additional 100,000 ha of terrestrial habitat suitable for the Javan leopard.

In July 2021, Sintas Indonesia Foundation facilitated a webinar for the Belambangan Biosphere Reserve's Forum to discuss the integration of Javan leopard conservation into the Belambangan Biosphere Reserve management plan. The webinar became the largest event ever held to promote Javan leopard conservation, with nearly 700 participants from various stakeholder groups, including provincial government officials, park managers, local NGOs, university scholars, the private sector and the public. The main outcomes of the webinar were the adoption of the Javan leopard as the Belambangan Biosphere Reserve's flagship speciesnow appearing in its logo-increased public recognition of and support for the Javan leopard and for biodiversity conservation in the Reserve, and a call for investment from interested parties to support the implementation of the Reserve's management plan.

This initiative could potentially be replicated in the other UNESCO Biosphere Reserves in Java (Cibodas, BromoTengger-Semeru-Arjuno, Merapi-Merbabu-Menoreh, and Karimun Jawa-Jepara-Muria). Together, these reserves secure more than 240,000 ha of core areas and provide $>300,000$ ha of terrestrial buffer zone, and could greatly increase the chances for long-term survival of the Javan leopard.

We thank the Belambangan Biosphere Reserve's Forum, Meru Betiri National Park, Alas Purwo National Park, Baluran National Park, East Java Natural Resources Conservation Agencies, East Java Forestry Agency, Yayasan Konservasi Elang Indonesia, and the National Geographic Society.

HARIYO TABAH Wibisono (৫ orcid.org/0000-0002-0311-3700)

San Diego Zoo Wildlife Alliance, Escondido, USA

E-mail h.wibisono@sintas.or.id

ERWIN WILIANTO (๑ orcid.org/0000-0003-1217-3614) and RIZKI AMalia AdINDA PUTRI (๑ orcid.org/0000-0001-97289725) Sintas Indonesia Foundation, Bogor, Indonesia

This is an Open Access article, distributed under the terms of the Creative Commons Attribution licence CC BY 4.0 .

\section{Dihing-Patkai and Raimona, Assam's new National Parks}

Two new National Parks have been declared by the government of Assam, India, one through the upgrading of an existing protected area. The $111 \mathrm{~km}^{2}$ Dihing-Patkai Wildlife Sanctuary in eastern Assam, established in 2004, was upgraded to a National Park on 15 June 2021, with a new total area of $234 \mathrm{~km}^{2}$. In western Assam, a part of Ripu Reserved Forest was declared as Raimona National Park on 8 June 2021, covering a total of $422 \mathrm{~km}^{2}$. Raimona is contiguous with Bhutan's Phibsoo Wildlife Sanctuary and West Bengal's Buxa Tiger Reserve, thus forming a large transboundary protected wilderness of $1,459 \mathrm{~km}^{2}$. Raimona is also part of the buffer zone of Manas Tiger Reserve.

Dihing-Patkai is dominated by lofty hollong Dipterocarpus macrocarpus trees, and Raimona by tall sal Shorea robusta trees. Primates common to both new National Parks include the slow loris Nycticebus bengalensis and Assamese macaque Macaca assamensis. Raimona is home to the golden langur Trachypithecus geei, and Dihing-Patkai to the stump-tailed Macaca arctoides and pig-tailed Macaca leonina macaques, capped langur Trachypithecus pileatus and hoolock gibbon Hoolock hoolock. Other notable mammals occurring in both areas are the elephant Elephas maximus, black bear Ursus thibetanus, tiger Panthera tigris, clouded leopard Neofelis nebulosa, marbled cat Pardofelis marmorata, dhole Cuon alpinus and gaur Bos gaurus. 